Research Note

\title{
Corrective Feedback and EFL Learning Style
}

\section{Steven Samie}

International Contribution College

Fukuoka, Japan

Corresponding author: stevennzd@hotmail.com

\section{About the author}

Steven Samie is currently pursuing his Master's degree in the field of applied linguistics from Otago University, New Zealand. He has been teaching English at schools and colleges in Fukuoka, Japan since 2010 and is now teaching at International Contribution College, Japan. His main research interests are sociolinguistics, English as a Foreign Language (EFL), Second Language Acquisition (SLA), and Critical Discourse Analysis (CDA). As an action researcher, he has been writing research articles with focus on the current issues in the educational system of Japan. 


\section{Abstract}

The present study is an attempt to address an important issue for an instructor in the classroom. It begins with an account of how to provide Corrective Feedback (CF) for individuals so that they have the highest rate of uptake in the classroom, then it is followed by definition of the concept in its general sense of the term. Next, the study has provided information on some of the previous studies along with the researcher's insights on the issue. Finally, the essay concludes by explaining how this term project will help me change the instructor's attitude in my future teaching in the classroom. Some suggestions for fellow instructors are provided to give them some food for thought.

Keywords: Corrective feedback, Learning style, EFL

\section{Introduction}

The researcher has always pondered upon the issue of correcting English language mistakes of Japanese learners in the classroom. However, finding out the most effective way of repairing the students' erroneous sentences has been too thorny a problem at times. Through a comprehensive review of literature on this concept, the author realized that Corrective Feedback $(\mathrm{CF})$ provides more considerable perspective on this critical issue of mistake correction in the field of English language teaching (ELT).

This comprehensive essay aims to present a short introduction of Corrective Feedback $(\mathrm{CF})$ as a subject which has been of great significance to English language teachers by exploring what its nature is and reviewing the existing literature to see how the subject has been investigated by the scholars in the field.

\section{Specific Issues to Address}

To begin with, Corrective Feedback (henceforth $\mathrm{CF}$ ) is an age-old educational praxis which can plausibly be associated with virtually anything we intend to acquire (Evans, Hartshorn, McCollum, \& Wolfersberger, 2010; Hattie \& Timperley, 2007). As Russell and Spada (2006) define it, in the process of language learning, the term corrective feedback concerns any corrective comment supplied to a learner, coming from every resource containing proof of a learner's errors in terms of language structure. Ever since the advent of "corrective feedback: to give or not to give" enigma, EFL teachers have always wondered how CF ought to be delivered so that English as a Foreign Language (EFL) learners could accomplish maximum pedagogical outcomes. Thus, this has intrigued researchers in the field of EFL to delve into the processes through which $\mathrm{CF}$ could ease or hinder language development and to lead to various levels of teaching efficiency. Over time, a barrage of research studies has been conducted focusing on various variables which may increase the efficiency of CF in the foreign language classroom. Many descriptive studies have been carried out to explore the incidence of feedback and learners' uptake (students' grasping of the provided feedback for an error), and learners' conceptualisation of feedback (Lyster, 1998; Egi, 2010). Moreover, experimental research studies have probed the impact of diverse kinds of feedback (Li, 2010; Lyster \& Saito, 2010). It is noteworthy that 


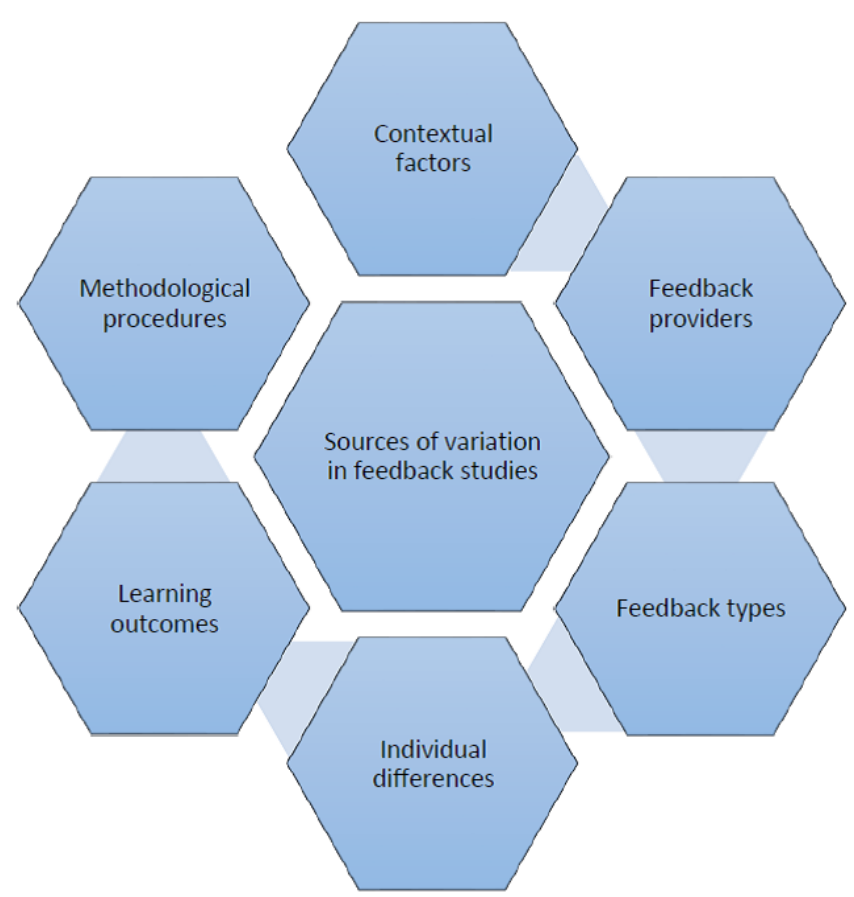

Fig. 1 Sources of Variation in Feedback Studies as Suggested by Ellis (2010)

both research types have broken new ground in second language teaching.

The previous research findings have revealed that CF can undoubtedly be beneficial for students if it concentrates on specific linguistic forms and structures and in specific contexts and in particular ways. Yet, the research studies have had an inclination to concentrate on group findings, and not sufficient attention has been paid to the reasons as to why some individuals neglect to take advantage of the practice. Conceivably, this tends to be the problem which is of more significance. If EFL teachers pay heed to the prerequisites to be fulfilled before CF could prove influential, they seem to be able to develop strategies and techniques that will benefit the majority of individuals in the classroom. Therefore, the question which arises is: what are those conditions requiring to be explored? One of these conditions could be teachers' awareness of the learning styles that each individual brings to the class with them. As of yet, there are no conclusive research studies in the literature investigating how learning styles of the language learners could contribute to the better uptake of the CF types which are provided for them in the classroom. Therefore, it can be a crucial topic for further research in the future.

\section{Oral and Written CF}

Up to the present day, there has been an abundance of research studies on Oral Corrective Feedbacks $(\mathrm{OCF})$ and Written Corrective Feedbacks (WCF) exploring their effectiveness from various dimensions with different variables of interest. The majority of the research designs, which many scholars in the field have adopted so far, are descriptive studies, experimental and quasi-experimental designs. All of them have 
proven the practicality of $\mathrm{CF}$ and the necessity of its presence in the process of language learning in a foreign language classroom. As illustrated in Figure 1, Ellis (2010) has suggested a framework of variables that has been employed in the studies on CF. They include contextual factors, feedback providers, feedback types, individual difference factors (covering both learner and teacher variables), learning outcomes, and methodological procedures.

According to Lyster and Ranta (1997), there exist six kinds of CF: recasts, explicit correction, metalinguistic feedback, clarification request, elicitation, and repetition. Some scholars refer to recasts and explicit correction as input-providing given the fact that they include the correct structures, and output-prompting correction stands for the other corrective methods that support learner repairs. There is another instance of such opposition for these feedback moves called implicit/explicit polarity hinging upon whether learners' awareness is visibly directed towards linguistic structures. Recast types belong to the implicit extreme, and metalinguistic feedback and explicit feedback are at the explicit extreme.

\section{Learners' Uptake}

As defined by Lyster and Ranta (1997), uptake denotes a learner's reactive move that instantly ensures the teacher's feedback. Uptake has been considered as a yardstick of the efficacy of feedback, for it could act as evidence for the student's perceiving and assimilation of the provided feedback (Egi, 2010; Lyster and Ranta, 1997). According to Swain (1995), uptake also comprises a kind of 'pushed output' through which students likely engage in metalinguistic reflection, hypothesis testing, and active rehearsal of recently or previously acquired linguistic items. Despite the debate that uptake could ease the outgrowth of learning a second language, the literature lacks sufficient empirical studies in order to substantiate its practicality as a contributory factor in learning a foreign language. There are only two studies that investigate the connections between uptake and students' test scores (Loewen, 2005).

\section{Personality Oriented Factors}

As Ellis (2010) puts it, individual factors constitute various elements such as age, language aptitude, memory, learning style, motivation or beliefs, and contextual factors which are believed to interpose the way students are involved in feedback and eventually grasp it. The issue of individual factors has not been the foci of attention of researchers and scholars specializing in the realm of CF studies. However, a vast variety of learner differences has been substantiated as to how learners reply to their teacher's comments (Ferris, 2006; Ferris and Hedgecock, 2005). Moreover, numerous elements have proven to play a part in this variety. For instance, students' feelings towards the validity of teacher's feedback (Goldstein \& Conrad, 1990), content knowledge (Conrad \& Goldstein, 1999), receptivity or resistance to revision (Enginarlar, 1993), motivation (Goldstein, 2006), beliefs (Storch \& Wigglesworth, 2010), or simply the lack of correspondence thereof between the teacher's response and the students' expectations (Hyland, 2003). Even though the investigation of individual learner factors was not directly pursued in any of those research projects, there exist several 


\begin{tabular}{|c|c|}
\hline Visual or spatial & $\begin{array}{l}\text {-They have a tendency to use } \\
\text { pictures,images, and spatial undestanding }\end{array}$ \\
\hline Aural or auditory & $\begin{array}{l}\text { - They have a tendency to use sound } \\
\text { and music }\end{array}$ \\
\hline Verbal or linguistic & $\begin{array}{l}\text { - They have a tendency to use } \\
\text { words, both in speech and writing }\end{array}$ \\
\hline Physical or kinesthetic & $\begin{array}{l}\text { - They have a tendency to use their } \\
\text { body, hands, and sense of touch }\end{array}$ \\
\hline $\begin{array}{l}\text { Logical or } \\
\text { mathematical }\end{array}$ & $\begin{array}{l}\text { - They have a tendency to use } \\
\text { logic,reasoning, and systems }\end{array}$ \\
\hline Social or interpersonal & $\begin{array}{l}\text { - They have a tendency to learn in } \\
\text { groups or with other people }\end{array}$ \\
\hline $\begin{array}{l}\text { Solitary or } \\
\text { intrapersonal }\end{array}$ & $\begin{array}{l}\text { - They have a tendency to work alone } \\
\text { and use self-study }\end{array}$ \\
\hline
\end{tabular}

Fig. 2 Seven Universally-acknowledged Learning Styles (Reid, 1995)

pertinent studies concerning how students react to the CF provided (Esteban \& Roca de Larios, 2010; El Ebyary \& Windeatt, 2010).

\section{Learning Styles}

Today, the incontrovertible fact that no individual acquires a lesson precisely the same as their peers do and that the learners demonstrate a preference to learn things differently is universally acknowledged. As Matthews and Hamby (1995) maintain, as educationalists, all of us have encountered the scientific truth that students learn in different ways. It is compelling and concrete evidence for this proposition that all teachers teach variegated classes similarly, yet, the learners' achievements tend to be different in the end. One notion that could clarify the diversity in individuals' accomplishment of learning a second language is the concept of learning style, which has been studied for its crucial part in educational success on the whole. As defined by Reid (1995), learning style concerns a student's innate, constant and preferred way of taking in knowledge, processing and preserving the incoming data and new capabilities. Figure 2 shows a tabulation of the seven globally established learning styles. 


\section{Studies Linking Learning Styles to Students' Achievements}

The factor which has awakened researchers' curiosity in learning styles, is the research findings regarding the correlation between learning styles and teaching styles, which functions as a component resulting in the positive educational outcomes of postsecondary students (Dunn et al., 1995; Ellis, 1989; Griggs \& Dunn 1996; Hall \& Moseley, 2005). As stated by Cassidy (2004), the enthusiasm that has been observed in the effect of learning styles on academic achievement illuminates that research studies have moved one step further examining the old-school variables like intelligence and motivation trying to reveal elements influencing educational achievements. As Entwistle (quoted in Drysdale (1984)) has demonstrated, success and failure in academic performance in tertiary education are affected by the consonance between the way materials are offered and the way learners organize and handle them. Moreover, Nelson et al. (1993) observed a relationship between learning styles and improved GPA scores. Dunn et al. (2009) discovered that informing the learners of their learning styles and assisting them to acquire study skills congruent with their preferred learning styles had a positive impact on their academic achievements. In the same vein, O'Brien (1991), conducted a study on subjects from various fields namely- business, education, and arts and sciences, and perceived that variety in learning styles was related to academic success. According to the findings of a metaanalysis of 42 experimental studies, Dunn et al. (1995) assert that learners taught by a method consonant with their learning styles outperform those whose learning styles are incompatible with the teaching method. Along the same line, Griggs and Dunn (1996) contend that individuals learning from a method congruent with their desirable learning styles perceive more academic accomplishments and are more optimistic towards learning.

\section{Conclusion}

Prior to getting acquainted with the issue of $\mathrm{CF}$ from the researchers' perspective and in scientific terms, the author had always had a rough idea of repairing students' errors and most of the time overlooked them. It is common that EFL teachers tend to correct the learners' errors using one kind of CF type that was mostly explicit feedback without paying attention to the fact that every learner is totally different and has their own particularities, which should be taken into account while dealing with those errors. However, as summarized above, there are many state-of-the-art researches focusing on CF within the field of Applied Linguistics. There are a variety of factors when it comes to providing CF for the learners, such as implicit/explicit, direct/indirect, learning styles, personality types, etc., many of which have shed light on the author's understanding and practice in English classrooms at Japanese high schools. In fact, those factors are really important in order to help the learners make the most of the CF provided for them. The main conclusion here is that CF based on individual differences is the elephant in the room in EFL classes. While providing CF to their students, EFL teachers tend to disregard factors such as age, language aptitude, memory, motivation or beliefs, contextual factors, and learning styles (Ellis, 2010). In the same vein, Kang 
(1999) maintains that EFL students are different not only regarding their aims for studying English language, but also in terms of individual differences in learning style due to diversities in their educational, ethnic, and cultural backgrounds that they bring with them to the classroom.

Providing CF for the learners is absolutely helpful in a specific context, provided that it focuses on particular structures and is delivered in a way that suits the learners' individual needs. However, projects up till now tend to address collective findings. The reasons behind learners' failures and the benefits they receive from the $\mathrm{CF}$ in the class were ignored by the previous researchers (see also Choi and $\mathrm{Li}, 2012$ ). It is unarguable that this issue must be of utmost importance to EFL teachers and researchers in the field. This claim will be advantageous for standardized classes where there are at most eight to ten students sitting in the classroom, otherwise, it might be highly idealistic in practice to adapt the CF types to each language learners' learning style when it comes to large classes. In such classes, the teachers will rightly have to adopt a one-size-fits-all approach by providing only one kind of CF for all the learners' errors. In small-size classes, the teachers are expected to utilize variegated CF types according to the learners' learning styles which have already been explored through questionnaires upon the launch of the course. It is a fact universally acknowledged that language learners do need to be corrected, yet, the crucial point to consider is that how EFL teachers repair their faulty sentences so pertinent to their learning styles that they can grasp the CF as smoothly as possible. The learners, as some of them stated in the semi-structured interviews, expect their teachers to pay the required amount of attention they deserve individually, rather than collectively. As soon as they are regarded as an important entity, they come to participate in the process of learning more actively and listen to the CF types provided by their teachers more attentively, which consequently leads to a high level of lesson achievements (Esteban, N. M. \& De Larios, J. R., 2010; Ebyary \& Windeatt, 2010). To conclude, individual attention on the part of the teacher to adapt the CF types to learners' learning styles is the building block of an English class seeking to achieve the maximum learning outcome (see also Matthews and Hamby, 1995). One specific CF prescribed for all the students attending a foreign language course will not bear the desirable fruits, the seeds of which are planted by curriculum developers and course designers at schools and language institutes.

\section{Reflection}

Gleaning rich literature and pursuing many papers on this topic helps EFL teachers extend their viewpoints on one of the most disturbing issues to both EFL teachers and researchers. There are numerous issues regarding $\mathrm{CF}$ which teachers should try to practice in their actual classroom teaching sessions, some of which are as follows:

1. Teachers should try to make use of various devices to pinpoint EFL learners' learning styles and provide instructional alternatives to address their differences. By doing so, they should help the learners recognize their dominant learning styles because even the students themselves don't have the faintest idea about their prevailing learning styles.

2. Teachers should endeavor to make EFL learning/teaching activities successful. Educators are required 
to understand and respect learners' variegated learning styles and attempt to create a maximum learning atmosphere for individuals.

3. Teachers should do their best to offer CF types to adapt to learners' learning styles while simultaneously motivate learners to diversify their learning style preferences.

In sum, the way EFL teachers treat their learners' errors determines how much they genuinely care about the pedagogical outcomes of their classrooms and curriculums. There are many issues that the author has decided to address differently in his classroom teaching, and would also like to recommend his colleagues to follow the suit if they have never considered individual factors when providing CF for their learners. The author calls this a 'paradigm shift' in his teaching. All the issues included in the syllabus are highly crucial to be practiced in real life teaching. The majority of the subject matters discussed above are the ones that are usually ignored by language teachers. Thus, the author believes that reading articles on these scientific issues is a must for all practitioners and those dealing with foreign language teaching. The author values learning theories and teaching as a complicated science because teaching is an undertaking which requires general knowledge of the language and some experience. All the foreign language teachers, no matter what level, age group, or gender they teach, are required to update themselves by learning about the theories and various issues through the numerous variables, which they might encounter in teaching. This learning could drastically help them teach and assess their learners and their learning activities much more efficiently while facilitating the learning process and enhancing the learning outcomes in the classrooms. If EFL teachers adopt a learner-based teaching approach, they should meet both the needs of the students and the school curriculum's expectations in the best way.

\section{References}

Cassidy, S., 2004. "Learning Styles: An Overview of Theories, Models, and Measures." Educational Psychology, Vol. 24, No. 4, pp. 419-444.

Choi, S. Y. and Li, S., 2012. "Corrective Feedback and Learner Uptake in a Child ESOL Classroom." RELC Journal, Vol. 43, Issue 3, pp. 331-351.

Conrad, S. M. \& Goldstein, L. M., 1999. "ESL Student Revision after Teacher-written Comments: Text, Contexts, and Individuals." Journal of Second Language Writing, Vol. 8, No. 2, pp. 147-179.

Drysdale, J., 1984. Singapore, Struggle for Success (p. 80). Singapore: Times Books International.

Dunn, R., Griggs, S. A., Olson, J., Beasley, M. \& Gorman, B. S., 1995. "A Meta-analytic Validation of the Dunn and Dunn Model of Learning-style Preferences." The Journal of Educational Research, Vol. 88, No. 6, pp. 353-362.

Dunn, R., Honigsfeld, A., Doolan, L. S. and Bostrom, L., 2009. "Impact of Learning-Style Instructional Strategies on Students' Achievement and Attitudes: Perceptions of Educators in Diverse Institutions." The Clearing House, Vol. 82, No. 3, pp. 135-140.

Egi, T., 2010. "Uptake, Modified Output, and Learner Perceptions of Recasts: Learner Responses as Language Awareness." The Modern language Journal, Vol. 94, No. 1, pp. 1-21. 
Ebyary, K. E. \& Windeatt, S., 2010. "The Impact of Computer-based Feedback on Students' Written Work." International Journal of English Studies, Vol. 10, No. 2, pp. 121-142.

Ellis, R., 1989. Understanding Second Language Acquisition (Vol. 31). London, UK: Oxford University Press.

Ellis, R., 2010. "A Framework for Investigating Oral and Written Corrective Feedback." Studies in Second Language Acquisition, Vol. 32, No. 2, pp. 335-349.

Enginarlar, H. 1993. "Student Response to Teacher Feedback in EFL Writing." System, Vol. 21, No. 2, pp. 193-204.

Esteban, N. M. \& de Larios, J. R., 2010. "The Use of Models as a Form of Written Feedback to Secondary School Pupils of English." International Journal of English Studies, Vol. 10, No. 2, pp. 143-170.

Evans, N., Hartshorn, J., McCollum, R. \& Wolfersberger, M., 2010. "Contextualizing Corrective Feedback in Second Language Writing Pedagogy." Language Teaching Research, Vol. 14, pp. 445-464.

Ferris, D. R., 2006. "Does Error Feedback Help Student Writers? New Evidence on the Short-and Longterm Effects of Written Error Correction." Feedback in Second Language Writing: Contexts and Issues, Vol. 81104.

Ferris, D. R. \& Hedgcock, J. S., 2005. Teaching ESL Composition: Purpose, Process, and Practice. Mahwah, NJ: Erlbaum.

Griggs, S. \& Dunn, R., 1996. "Learning Styles of Asian-American Adolescents." Emergency Librarian, Vol. 24, No. 1, pp. 8-13.

Goldstein, L., 2006. "Feedback and Revision in Second Language Writing: Helping Learners Become Independent Writers." In K. Hyland and F. Hyland (Eds), Feedback in Second Language Writing: Contexts and Issues, pp. 185-205. New York: Cambridge University Press.

Goldstein, L. \& Conrad, S., 1990. "Student Input and Negotiation of Meaning in ESL Writing Conferences." TESOL Quarterly, Vol 24, No. 3, pp. 443-460.

Hall, E. \& Moseley, D., 2005. "Is There a Role for Learning Styles in Personalised Education and Training?" International Journal of Lifelong Education, Vol. 24, No. 3, pp. 243-255.

Hattie, J. \& Timperley, H., 2007. "The Power of Feedback." Review of Educational Research, 77, pp. 81-112. Hyland, F., 2003. "Focusing on Form: Student Engagement with Teacher Feedback." System, Vol. 31, No. 2, pp. 217-230.

Kang, S., 1999. "Learning Styles: Implications for ESL/EFL Instruction." English Teaching Forum, Vol. 37, No. 4, pp. 6-11.

Li, S., 2010. "The Effectiveness of Corrective Feedback in SLA: A Meta-analysis." Language Learning, Vol. 60, No. 2, pp. 309-365.

Loewen, S., 2005. "Incidental Focus on Form and Second Language Learning." Studies in Second Language Acquisition, Vol. 27, No. 3, pp. 361-386.

Lyster, R., 1998. "Recasts, Repetition, and Ambiguity in L2 Classroom Discourse." Studies in Second Language Acquisition, Vol. 20, No. 1, pp. 51-81.

Lyster, R. \& Ranta, L., 1997. "Corrective Feedback and Learner Uptake." Studies in Second Language Acquisition, Vol. 19, No. 1, pp. 37-66. 
Lyster, R. \& Saito, K., 2010. "Oral Feedback in Classroom SLA: A Meta-analysis." Studies in Second Language Acquisition, Vol. 32, No. 2, pp. 265-300.

Matthews, D. B. \& Hamby, J. V., 1995. "A Comparison of the Learning Styles of High School and College/University Students." The Clearing House, Vol. 68, No. 4, pp. 257-261.

Nelson, B., Dunn, R., Griggs, S. A. \& Primavera, L., 1993. "Effects of Learning Style Intervention on College Students' Retention and Achievement." Journal of College Student Development, Vol, 34, No. 5, pp. 364-369.

O'Brien, T. P., 1991. "Relationships among Selected Characteristics of College Students and Cognitive Style Preferences." College Student Journal, Vol. 25, pp. 492-500.

Reid, J. M., 1995. Learning Styles in the ESL/EFL Classroom. CA, USA: Heinle \& Heinle Publishers, Russell, J. \& Spada, N., 2006. "The Effectiveness of Corrective Feedback for the Acquisition of L2 Grammar." In J. M. Norris, and L. Ortega (eds.), Synthesizing Research on Language Learning and Teaching, XIV, pp. 133-164.

Storch, N. \& Wigglesworth, G., 2010. "Learners' Processing, Uptake Retention of Corrective Feedback on Writing: Case Studies." Studies in Second Language Acquisition, Vol. 32, No. 2, pp. 303-334.

Swain, M., 1995. "Three Functions of Output in Second Language Learning." In Cook, G. and Seidlhofer, B. (eds), Principle and Practice in Applied Linguistics (pp. 125-144). London, UK: Oxford University. 